\title{
REFLEXÕES BAKHTINIANAS ACERCA DA MÁSCARA AUTORAL EM “HISTORIETA”, DE LUIZ PACHECO
}

Rosana Letícia Pugina*

Resumo: De acordo com Bakhtin (2011), uma das principais formas de dialogismo na literatura é a relação entre autor e herói por meio da exotopia. Assim, propõe-se estudar os conceitos de autor e autoria em "Historieta" (2004), de Luiz Pacheco. O objetivo é compreender como as noções bakhtinianas sustentam o fio narrativo no conto ao mesmo tempo em que favorecem um jogo de máscaras entre autor, herói e personagem. A metodologia é exploratória, qualitativa e de cunho bibliográfico. No final, espera-se ter verificado as formas de constituição dialógica edificadas no conto por meio dos conceitos bakhtinianos de autor, autoria e exotopia.

Palavras-chave: Bakhtin. Exotopia. Autoria. "Historieta".

Abstract: According to Bakhtin (2011), one of the main forms of dialogism in literature is the relationship between author and hero through exotopy. Thus, it is proposed to study the concepts of author and authorship in "Historieta" (2004), by Luiz Pacheco. The objective is to understand how Bakhtinian notions sustain the narrative thread in the story while favoring a masks' game between author, hero and character. The methodology is exploratory, qualitative and bibliographic. In the end, we hope to have verified the forms of dialogical constitution established in the tale through the Bakhtinian concepts of author, authorship and exotopia.

Keywords: Bakhtin. Exotopia. Authorship. "Historieta".

Resumen: Según Bajtín (2011), una de las principales formas de diálogo en la literatura es la relación entre autor y héroe por medio de la exotopía. Por lo tanto, se propone estudiar los conceptos de autor y autoría en "Historieta" (2004), de Luiz Pacheco. El objetivo es comprender cómo las nociones bajtinianas respaldan el hilo narrativo de la historia y favorecen un juego de máscaras entre autor, héroe y personaje. La metodología es exploratoria, cualitativa y bibliográfica. Al final, se espera haber comprobado las formas de constitución dialógica construidas en el cuento por medio de los conceptos bajtinianos de autor, autoría y exotopía. Palabras claves: Bajtín. Exotopía. Autoría. "Historieta".

\section{Introdução}

\footnotetext{
* Doutoranda em Estudos Literários na Universidade Estadual Paulista (UNESP/FCLAr). Bolsista pelo CNPq. Bolsista de doutorado-sanduíche pela CAPES (Universidade Nova de Lisboa, Portugal). http://orcid.org/o0oo-0003-0917-0922
} 
Conforme o Bakhtin, uma obra literária é um objeto estético e, como tal, propõe e enceta um diálogo que se abre a réplicas das mais díspares. Neste jogo, a palavra precisa do outro para significar, pois a compreensão é um processo ativo e responsivo, o qual se estabelece por meio do dialogismo, ou seja, das relações dialógicas que se dão entre as vozes que coexistem socialmente. Na literatura, um dos pilares constitutivos das relações dialógicas é o elo entre o autor e o herói, o que irá determinar a polifonia na obra, uma vez que o distanciamento - concretizado no conceito de exotopia - permite o diálogo equipolente entre essas vozes, as quais, por sua vez, estão em permanente diálogo com a linguagem viva e inconclusa da vida cotidiana, em meio a um complexo processo histórico de descentralização da palavra.

Em vista de tal aporte teórico, propõe-se, neste trabalho, uma leitura de "Historieta" (2004 [1971]), do escritor luso Luiz Pacheco (1925-2008), à luz das reflexões de Bakhtin (2011) acerca da autoria, com vistas a compreender como tais concepções sustentam o fio narrativo no conto ao mesmo tempo em que possibilitam um jogo de máscaras entre o autor, o herói e a personagem. Além de Luiz ser o nome do autor empírico, na narrativa, o herói e também o narrador são uma pessoa só: um homem que conta a "historieta" de um suposto amigo, o qual é o seu próprio reflexo, tendo, inclusive, o seu nome: Luiz. Instala-se, portanto, uma dubiedade, primeiramente, entre o autor empírico, Luiz Pacheco, e o narrador, também Luiz, e, em segundo lugar, entre o narrador, Luiz, e o seu "duplo”, o amigo: "um sujeitinho que já tinha idade para ter juízo (andava nos quarenta e picos)" (PACHECO, 2004, p. 33).

Sobre o autor português, a sua personalidade peculiar evidencia-se em duas facetas. Como editor, divulgou personalidades literárias importantes em Portugal, tais como Mário Cesariny, António Maria Lisboa, Manuel de Lima e Herberto Helder. Como autor, nas palavras da escritora lusa Natalia Correia (200o, p. 431-432), foi "uma das poucas vozes genuínas da ficção portuguesa”. Desta forma, Pacheco revela um estilo muito pessoal de produção ficcional, tida como rebelde a enquadramentos estéticos, e que, por isso, mostra uma originalidade baseada em uma requintada busca pela liberdade. Neste ímpeto, recorre à temática das reminiscências, daí a confusão de vozes tão presente em sua arte literária. 
Após as leituras realizadas, espera-se ter como resultado uma compreensão acerca do jogo impresso ao conto que compõe o corpus da análise aqui proposta com a finalidade de lançar luz ao mecanismo de máscara autoral usado por Luiz Pacheco na obra.

\section{Reflexões sobre o dialogismo em Bakhtin: a autoria}

Bakhtin iniciou as suas reflexões literárias a partir da noção de texto. Para ele, “onde não há texto não há objeto de pesquisa e pensamento" (BAKHTIN, 2011, p. 307). Assim, texto é entendido, no sentido amplo, como qualquer conjunto coerente de signos, formado por dois elementos que o determinam como enunciado: a sua intenção e a realização dessa intenção. Apoiado nestes conceitos, o filósofo russo desenvolveu a concepção de dialogismo. Como materialização deste fenômeno estão as relações dialógicas, as quais se sustentam também no conceito de autoria advindo das reflexões bakhtinianas: a procura da própria palavra pelo autor é, basicamente, a procura pelo gênero e pelo estilo, a procura pela posição de autor.

Em O problema do texto na linguística, na filologia e em outras ciências humanas (BAKHTIN, 2011), o estudioso russo, já no começo de suas pesquisas, afirma que: "todo texto tem um sujeito, um autor" (BAKHTIN, 2011, p. 308). Assim, o enunciado literário é a representação da consciência de um autor, a qual é, basilarmente, a consciência que forma outra consciência: a do herói e do seu mundo. Por isso, o autor sabe mais do que o herói: foi ele que articulou a transposição do plano da vida para o plano da arte ao mesmo tempo em que criou um ser para habitar esta nova realidade. $\mathrm{O}$ autor possui, desta forma, um excedente de visão que lhe dá o princípio de acabamento da obra literária. É exatamente esse excedente que relativiza a criação da outra consciência.

A este respeito, segundo Tezza (2007, p. 239), “a relação criadora é sempre marcada por um princípio básico: uma exotopia, isto é, o fato de uma consciência estar fora de outra, de uma consciência ver a outra como um todo acabado, o que ela não pode fazer consigo mesma”. Com base nisso, cada ser humano está, em todo momento, 
vivendo um acontecimento aberto, da mesma forma que o herói vive um acontecimento aberto por meio da sua unidade criativa, a qual lhe é dada pelo autor, que sabe e enxerga mais do que a personagem. Para ilustrar, Marchezan (2015) cita a análise que o filósofo fez das obras de Dostoiévski, nas quais não há um autor que fala sobre o herói, mas, sim, dialoga, polemiza e debate com ele, tal qual o estudioso russo nos mostra em Problemas da poética de Dostoiévski (BAKHTIN, 1997). Nas palavras da autora, é na prosa literária, singularmente nos romances de Dostoiévski, que o jogo de vozes transparecerá toda a sua complexidade na exibição de "consciências equipolentes, vozes plenivalentes e o caráter inconcluso da vida" (MARCHEZAN, 2015, p. 197).

Faraco (2006, p. 37), com fins didáticos e também refletindo sobre a autoria em Bakhtin, diz que, primeiramente, o estudioso russo observa a existência de dois "tipos de autor": o autor-pessoa, ou seja, o escritor, o artista; e o autor-criador, isto é, "a função estético-formal engendradora da obra”. Claramente, tais acepções de autoria se dão em continuidade, não de forma oposta ou paralela, uma vez que são complementares na constituição do tecido literário como um todo. A este respeito, segundo Marchezan (2015, p. 199)

toda esta dinâmica revela, pois, que não há um rompimento radical entre autorpessoa e autor-criador, nem uma completa alienação entre o autor-pessoa e sua obra. Seria admitir, em Bakhtin, o que ele critica no estruturalismo, no formalismo.

Com base nisto, na descrição das características do autor-pessoa e do autorcriador demonstradas a seguir, intenta-se destacar que ambos possuem papel essencial na criação literária, pois um não existe sem o outro. Logo, neste momento, compreendêlas “separadamente” é uma estratégia justificável pelo caráter expositivo desta parte da pesquisa.

A respeito do autor-pessoa, não são interessantes os processos psicológicos envolvidos na criação ou o depoimento do autor empírico sobre o seu processo de gênese literária porque este não experimenta os processos psicológicos criativos como tais, apenas os materializa na obra. Desse modo, o autor-pessoa não adentra a materialidade discursiva, uma vez que o seu papel é direcionar as vozes sociais ao autor-criador, o qual é responsável pela construção do quadro estético. Assim, "na obra, as ideias do escritor 
mudam de existência: transformam-se em imagens artísticas das ideias", pois, ao serem impressas ao todo artístico, tornam-se refração das ideias iniciais do autor-pessoa (FARACO, 2006, p. 40).

Já o autor-criador é, para Bakhtin, "um constituinte do objeto estético - mais precisamente, aquele constituinte que dá forma ao objeto estético, o pivô que sustenta a unidade do todo esteticamente consumado", de acordo com Faraco (2006, p. 37). Assim sendo, o autor-criador, centro artístico e axiológico da obra, é constitutivo do objeto estético porque dá forma a esse objeto. Marchezan (2015, p. 190) diz que, na obra literária, nem o objeto, muito menos o material, "são os agentes que captam o sujeito em um lance de passividade”. Para a pesquisadora, o papel de agente é do autor-criador, em sua função de cocriador, que "enforma/reenforma o conteúdo ao imprimir-lhe nova axiologia”. Logo, é responsável por concretizar a axiologia da composição artística por meio da relação que estabelece com o herói e o seu mundo: "ele os olha com simpatia ou antipatia, distância ou proximidade, reverência ou crítica, gravidade ou deboche, aplauso ou sarcasmo, alegria ou amargura, generosidade ou crueldade, júbilo ou melancolia, e assim por diante" (FARACO, 2006, p. 38).

Portanto, o autor-criador direciona as vozes sociais e as junta no todo artístico, por isso, o seu discurso não é o discurso do autor-pessoa: é sempre uma segunda voz que ordena o quadro estético. Em vista disso, o autor-criador está à frente, espacialmente de fora e temporalmente mais tarde do que o herói: “o próprio herói vive o tempo como nós o vivemos, isto é, sob o signo da urgência e do futuro, do mesmo modo como o seu espaço é um horizonte, à frente dele" (TEZZA, 2007, p. 249). Neste processo, o material e a forma composicional precisam ser "superados" para que possam embasar a forma arquitetônica, o que configura a "relativa autonomia" da obra literária, conforme Bakhtin (2011): a arte não confronta a realidade, ao contrário, a vida é um elemento essencial para a gênese artística, daí a sua "relativa autonomia”. Entretanto, destaca-se que a arte e a vida não se fundem nem se confundem: "ao dar nova forma ao conteúdo, o autor-criador penetra com empatia no objeto, sempre já saturado axiologicamente, para, sem se fundir com ele, de fora [...] (re)conformá-lo axiologicamente no mundo da cultura”. Ao mesmo tempo em que cria a obra, o autor-criador vai construindo a sua imagem por meio das 
relações dialógicas que vai estabelecendo com a esfera artística em que se assenta (MARCHEZAN, 2015, p. 190-191).

Com base em tais preceitos, o plano da vida, atravessada por inúmeras axiologias, é transposto para o plano da arte pelo autor-criador quando há a refração e a reacentuação desses valores, por conseguinte, a posição do autor-criador é também uma posição axiológica: ao posicionar-se, ele seleciona os valores que serão postos na obra, os quais se dão a partir de escolhas composicionais e de linguagem. Para isso, a linguagem é deslocada de seu uso comum para ganhar um acabamento artístico: “a palavra deve deixar de ser sentida como palavra: a tarefa do artista consiste em superar o material" (TEZZA, 2007, p. 255).

No ensaio O autor e a personagem (BAKHTIN, 2011), o filósofo russo reflete sobre a criação da personagem: "o autor acentua cada particularidade de sua personagem, cada traço seu, cada acontecimento e cada ato de sua vida” (BAKHTIN, 2011, p. 3). É na constituição do todo estético - autor-criador e herói - que a exotopia se faz mais necessária: no movimento de ver o outro de fora, está a chave para a criação do conceito de autor-criador, o qual, quando bem construído, irá afastar-se - em outro processo de exotopia - para dar gênese ao herói, ou seja, quanto mais o autor distancia-se do herói, mais este é acabado esteticamente. Esse quadro é montado porque, conforme Tezza (2007), necessariamente, o acontecimento estético pressupõe, ao menos, duas consciências que não podem coincidir.

Sobre isso, Marchezan (2015, p. 195) afirma que a relação entre essas duas consciências, estabelecida pela exterioridade e pela empatia, dá-se pela sua natureza dialógica, resultando em vários desdobramentos, tais como "a reflexão sobre o mundo da vida, sobre o ato ético e sobre a obra literária”. A este respeito, Bakhtin (2011, p. 341) nos diz: "eu tomo consciência de mim e me torno eu mesmo unicamente me revelando para o outro, através do outro e com o auxílio do outro”. Nota-se, nesta relação, que a própria constituição de uma consciência se assenta em outra consciência, que lhe é externa. Logo, o que nos interessa não é o que ocorre dentro dessa consciência, mas no limiar de uma para a outra, uma vez que se "entrecriam", porém, não se fundem. Em resumo, de forma conjunta, o "mundo da vida" e o "mundo da arte" coexistem na autoria, 
em um desdobramento entre o autor-pessoa e o autor-criador, enfaticamente, no domínio da literatura.

Com base em tais acepções, pode-se observar que, no caso do autor-pessoa, a palavra é monovocal ou univocal, isto é, o dialogismo é interno, constitutivo do discurso. Nela, é ouvida apenas uma voz, mesmo que esta seja marcada por outros discursos e encharcada pelo contexto histórico. Já no caso do autor-criador, a palavra é bivocal, pois o seu dialogismo se manifesta no segundo sentido, uma vez que a palavra do homem (autor-pessoa) foi transposta para o plano da arte (autor-criador), neste processo, foi refratada, daí as duas vozes. O ato criativo engloba, portanto, uma ação complexa de transposições refratadas da vida para a arte. Desta forma, a criação de um herói com consciência própria, apesar de ser resultado de outra consciência (o que limita a sua autonomia), realiza o autor na obra de arte verbal. Ao criar um novo ser, o autor entra em relação dialógica com este ser, pois reflete e refrata as suas vozes em uma dialogia tensa. A partir de tudo o que foi exposto até aqui, conclui-se que a autoria dá ao enunciado caráter de acontecimento histórico decisivo, pois o autor é aquele que se responsabiliza por sua ação discursiva.

Na sequência, passaremos à leitura do conto "Historieta”, de Luiz Pacheco (2004), à luz das reflexões apresentadas.

\section{Uma leitura bakhtiniana do conto "Historieta”, de Luiz Pacheco}

No geral, segundo os estudiosos de sua obra, o autor luso Luiz Pacheco escrevia em primeira pessoa, em tom confessional e autobiográfico. Martins (2007, p. 13) afirma que, em Pacheco, vida e obra estão em constante contato, porém, o seu veio artístico não intenciona falsear a realidade, mas, sim, ser "um gesto obstinado de lembrar que a obra afinal arranca-se das entranhas de quem a escreve”, portanto, separar ambas é “quase como uma heresia”. Já conforme Narciso (2012), é preciso ver, no universo pachequiano, a sua trajetória de artista que se refez como personagem. 
Sabe-se que "vida" e "arte" possuem naturezas diferentes, uma vez que se encontram em planos incomunicáveis, pois a vida é realidade e a literatura é “imaginação”, percepção esta que decorre das reflexões bakhtinianas. Em contrapartida, a literatura cria um mundo possível, o qual, mesmo no caso de uma autobiografia, é apenas uma narrativa, que sempre reconstrói o passado à luz do presente. É esta dialogia entre empirismo e gênese literária que estabelece o jogo de vozes autorais no universo pachequiano. Assim sendo, acerca da sua característica de se refazer na arte, George (2011) atesta que, neste processo, o autor luso transformou-se em testemunha de si mesmo ao se tornar “dois” Luiz Pacheco, o que se deu no emprego de suas vivências em seu projeto literário.

$\mathrm{Na}$ constituição das personagens centrais, quase sempre debruçadas em narrativas autobiográficas, a temática das aventuras sexuais e conjugais é recorrente. Os temas mais comuns são as suas confusões com a Ditadura Salazarista (1926-1968); a falta de dinheiro; as aventuras amorosas; a experimentação sexual; as relações de poder estabelecidas por meio do ato sexual; a natureza como forma de justificativa para quaisquer atos - de virtude e de vício; os conflitos advindos das relações entre pais, filhos e sociedade, singularmente quanto à educação cristã; a hipocrisia social; o estabelecimento dos papéis de gênero - homem e mulher - na coletividade e na alcova; o questionamento da heteronormatividade; o exercício sexual como um meio de esclarecimento; e o fingimento como caminho de adaptação do sujeito à dissimulação da sociedade.

Com base no jogo entre os papéis do autor empírico e das personagens da sua criação literária, Luiz Pacheco escreveu um conto que retrata tal questão, tão cara a sua obra como um todo: "Historieta”, publicado originalmente no Século Ilustrado, em 30 de outubro de 1971. Como é marca pachequiana, foi escrito em primeira pessoa, por um narrador protagonista, que conta uma breve história, daí o título do texto, sobre um “amigo" alcoólatra: "um sujeitinho que já tinha idade para ter juízo (andava nos quarenta e picos) e bebia de mais [sic]. Uma sede assim nunca se vira!” (PACHECO, 2004, p. 33). O enredo brinca com as máscaras que são produzidas dentro da problemática literária do autor Luiz Pacheco, por meio da utilização de uma linguagem intencionalmente popular e coloquial. 
Acerca da linguagem, segundo George (2011, p. 13-14), Pacheco escrevia de forma viva e pitoresca, pois usava um léxico vulgar e de baixo calão, repleto de termos populares, o que reforça a atmosfera coloquial da sua arte literária. Enfatiza-se, aqui, o momento histórico ao qual a obra do autor pertence: o regime militar português. No conto em questão, os exemplos são variados: "sujeitinho”, “cervejolas”, "tintaços”, "liso de todo", "macacadas", "bebedolas", "maluquitos", "tripas”, etc. Como arremate, utilizou também termos eruditos e vocabulário clássico, à moda "de Gil Vicente, Camões, Cavaleiro de Oliveira, Nicolau Tolentino ou Camilo Castelo Branco”.

A carga dramática do texto está no tom confessional do narrador, e também herói, a qual é acompanhada por uma forte ironia, que é resultante da criação de uma personagem que é, na verdade, uma projeção do próprio Luiz empírico. Em outras palavras, o Luiz, para não falar que é alcoólatra e assumir a sua ida a um hospital para a reabilitação, cria um “amigo”, também Luiz, para ser um “tipo” viciado em álcool e que precisa de ajuda urgentemente. Parece uma tentativa de autopiedade ou de escape numa primeira leitura. Desta forma, já no primeiro parágrafo, instala-se uma ambiguidade proposital entre as vozes que compõem o conto, pois há o Luiz narrador e o outro Luiz, o amigo alcoólatra:

acontece que o tipo usava o mesmo nome que eu. Malvada coincidência. Porque, no correr dos anos, e conhecíamo-nos de perto, frequentávamos quase os mesmos sítios, as complicações e sarilhos, alguns graves, em que me vi metido por causa dele e das suas rábulas não tiveram conta. Se os fosse aqui contar... mas pra quê relembrar misérias, cegadas, trapalhadas incríveis? (PACHECO, 2004, p. 33).

Mesmo usando tantas generalidades para se referir às aventuras que teve com o amigo, Luiz narra acontecimentos muitos próximos da vida de Luiz, o autor empírico, o qual teve inúmeros problemas financeiros durante a vida, além de ter tido variadas complicações conjugais e com o regime político do período salazarista. Há, assim, uma transposição de fatos da vida real de Luiz Pacheco para a personagem Luiz, o narrador, e também para o outro Luiz, seu amigo.

A partir de tal constatação e com base nos apontamentos bakhtinianos, pode-se afirmar que Luiz Pacheco é o autor-pessoa que responde pela criação de uma voz, já 
dentro do conto, a do autor-criador, cuja consciência dará gênese ao Luiz, herói e narrador, o qual, por sua vez, contará a "historieta" de um amigo, por ele criado, também chamado Luiz. Este último, duplo do Luiz narrador. O dialogismo está nas relações que se estabelecem entre as instâncias narrativas, todas elas canalizadas para a criação de um todo artístico dentro do conto selecionado.

Mais ao fim do conto, o herói, bastante lúcido, afirma, sobre o tal amigo, que: "No caso que ao de leve aqui lhes relatei e servirá para corroborar por um exemplo vivido o que o Carlos Plantier teve agora ocasião de inquirir e divulgar, ao tal bebedanas, [era] meu sósia ou alter ego" (PACHECO, 2004, p. 35, grifo do autor). Este indício aponta para a constituição das vozes que compõem o conto: há um discurso de moralidade social ao fundo, o qual leva Luiz, autor-pessoa, a discutir a exclusão advinda do alcoolismo. Resulta daí a criação do Luiz, o herói, e, por parte deste, a do “amigo”, ou seja, há aqui um indício do acobertamento de Luiz Pacheco empírico sob os véus das personagens criadas.

No trecho a seguir, nota-se a descrição de alguns fatos negativos que ocorreram com o herói em decorrência da amizade que possuía com o Luiz e da suposta confusão que as pessoas faziam entre eles:

\footnotetext{
Sei que perdi empregos (com que alegria!), fugiram-me mulheres (oh que alívio!) e uma data de oportunidades porreiras, das que levam uma criatura a almejar e confiar numa velhice mais tarde garantida e repousada. Só porque me confundiam com ele e eu nem sempre dispunha de álibis ou testemunhas idóneas que provassem a minha inocência nas muitas macacadas em que, por gosto ou teima de bêbado, ele se recreava (PACHECO, 2004, p. 33).
}

No excerto, é perceptível um tom de ironia relacionado ao fato de ter perdido empregos e companheiras, o que está explicitado nas expressões colocadas entre parênteses, como uma licença para a revelação dos pensamentos mais íntimos do herói - em forma de discurso indireto livre -, os quais não poderiam ser ditos em qualquer situação exatamente devido ao seu teor ácido. Percebe-se também certo sarcasmo na tentativa de se definir como ingênuo, característica esta que, ao lado do alcoolismo, favorecia alguns comportamentos de autossabotagem, sobretudo ao lado do seu amigo Luiz. 
Sobre isso, no conto, é possível notar a exotopia do qual fala Bakhtin (2011) por meio da criação das personagens, o que só ocorre devido ao distanciamento alcançado no momento do acabamento do ato artístico. No exemplo abaixo, observa-se que há um grande conhecimento do narrador acerca do temperamento do seu amigo:

Sem lhe poder evitar tais desmandos, não deixava por vezes (mas em silêncio) de lhe dar atenção. Até lhe invejava a franqueza, o desplante, o à-vontade no arrojo. Mas ele exagerava-me e muito, tornava-se caricato, quando não abominável. Destruindo, destruía-se; procurando atacar, raro atingia o alvo, embora os seus argumentos tivessem o doloroso tom das verdades declaradas. Mas os visados encolhiam os ombros e arranjavam a conhecida desculpa: são coisas de bêbado (PACHECO, 2004, p. 33, grifo do autor).

Assim, Pacheco, autor-pessoa, cria um excedente de visão que favorece a gênese de uma personalidade que se mistura à sua própria dentro do recorte literário. Em resumo, o autor-criador transpôs os traços de personalidade do Pacheco empírico, baseados em suas reminiscências - instabilidades financeiras, dívidas, aventuras sexuais, alcoolismo, problemas afetivos, libertinagem, confusões com a polícia e a ditadura, internações, etc. -, para o plano da arte. Como resultado, há um jogo de máscaras entre um e outro Luiz:

A certa altura, comecei a ficar preocupado. Aquilo assemelhava-se, na prática do dia a dia, assim a uma espécie de dupla personalidade. Eu e o Outro -, o bebedolas. Nem já percebia bem, atentando em ambos com lúcida curiosidade e temor, qual de nós iria - como dizer? - durar, afirmar-se em definitivo. [...] Ocasiões houve em que fomos os dois parar à esquadra: na hora de nos identificarem era a grande confusão. Um espanto (PACHECO, 2004, p. 33-34, grifos do autor).

Escolher criar uma personagem alcoólatra revela os laços entre o autor-pessoa e o autor-criador, isto é, a busca de uma consciência sobre o alcoolismo, que é vivido pelo próprio Pacheco empírico. Em outras palavras, ao criar uma personagem alcoólatra, Luiz Pacheco, autor-pessoa, está usando a exotopia para criar uma consciência sobre si mesmo, o que ocorre por meio da gênese de duas personagens também envolvidas com o vício de álcool. É o excedente de visão advindo da criação literária que favorece a existência de uma consciência sobre si, mesmo que tal processo tenha o seu 
desencadeamento a partir da utilização de personagens fictícias. O jogo de máscaras é libertador neste sentido.

Neste contexto, apesar de haver conexões entre Luiz Pacheco empírico e Luiz, o herói, estes dados não interessam à compressão do conto, uma vez que, segundo Bakhtin (2011), o autor-pessoa não adentra a obra, ele cria as condições para que ela aconteça. Tais vivências interessam ao autor-criador, o qual irá trabalhar com elas no plano estético. No caso, refratá-las de maneira que transgridam a norma vigente, isto é, as relações dialógicas estabelecidas entre as vozes que compõem o conto se dão também através da voz da moralidade em oposição à voz libertadora do autor-pessoa, realizada pelo autor-criador.

Em seguida, há várias passagens que mostram que o amigo, Luiz, era viciado em álcool, o que justifica o enredo da narrativa:

Escorropichava tudo. Cervejolas, principalmente, se o dinheiro abundava; senão, caía nos tintaços, na rasca bagaceira; liso de todo, era quanto viesse, fiado ou pago por beneméritos compinchas de balcão. Aparecem sempre, é só saber esperar. Pagam o vinho, estendem-nos o maço de cigarros, negam-se, porém, à sandes e ao galão e ao empréstimo ou cravanço. São os amigos do copo (PACHECO, 2004, p. 33, grifo do autor).

Verifica-se uma ligação entre a condição financeira da personagem e o tipo de bebida que consome: quando há dinheiro, toma cerveja, bebida mais leve e de baixo teor alcoólico; quando falta dinheiro, bebe vinhos de baixa qualidade e aguardente, bebidas mais fortes e de alto teor de álcool, o que, obviamente, resulta em cenas de mais desorientação e caos. No trecho há, ainda, a apresentação de alguns figurantes: os amigos de bar, pessoas que financiavam a bebedeira com o objetivo de rir das trapalhadas feitas pelos bêbados. Entretanto, tais "amigos" não se preocupavam com a alimentação ou com qualquer outro tipo de necessidade apresentada pelos companheiros de copo, fato este que demonstra as intencionalidades dessas amizades. A axiologia escolhida pelo autor-criador apresenta esta observação no final da narrativa: com esclarecimento, o herói reflete sobre os incentivos que são feitos para o uso indiscriminado de álcool pela sociedade, a qual, apesar dos riscos do alcoolismo, não 
busca alternativas para diminuir o consumo de álcool ou, ao menos, criar condições para que haja uma conscientização em massa sobre o vício alcoólico.

Como bebia demais, Luiz, o amigo, metia-se nas mais diversas desordens:

Na verdade, o abuso do álcool transtornava-o que era mesmo um disparate. Parecia outro. Metia-se com toda a gente, conhecidos e desconhecidos, amigos do coração e outros que nunca gramara. Não poupava ninguém. Língua afiada, atitudes desbragadas, insolência, revoltas súbitas, quem o podia aturar? E passada a crise, para cima de mim é que vinham... as iras, as censuras, caras torcidas, ameaças de pancadaria, perseguições injustas, vinganças a longo prazo. Que fazer? Eu às vezes nem me lembrava de nada do que ele tinha dito ou feito (PACHECO, 2004, p. 33, grifo do autor).

Luiz, o narrador, faz juízos de valor acerca das atitudes do amigo ao beber demasiadamente, o que demonstra que o autor-pessoa, por meio do autor-criador, cria outra consciência, a do herói, ligação esta que irá estabelecer uma dialogia entre o autorcriador e as personagens. O dialogismo que se dá neste processo surge da transformação da palavra monovocal, a do autor-pessoa, em palavra bivocal, a do herói, ou seja, aquela marcada por duas consciências, a do autor-criador e a da personagem, as quais não podem coincidir. No trecho, pode-se verificar a veracidade dessas relações no distanciamento existente entre as instâncias artísticas citadas: o autor-criador dá vida ao herói e, ao mesmo tempo, concede-lhe uma capacidade quase humana de reflexão sobre o cotidiano vivido. A criação de uma consciência para o herói confere-lhe o acontecimento do existir. Além disso, ao narrador, é dada ainda a competência de criação do outro, o Luiz amigo.

Nesta altura do conto, a partir de um posicionamento acerca das trapalhadas indesejáveis do amigo, surge a consciência sobre a existência do outro Luiz, existência esta completa, quase como um ser humano real:

Continuávamos (assim ou alternadamente?): um, abstémio, beberricando gasosas insonsas, comendo devagar um pacato iogurte; na mesa do lado, o fulano empinando cervejas umas atrás das outras, rindo-se como maluco que era ou se fazia (para me comprometer, tá visto), entaramelando ou sumindo a fala de tal modo que ninguém o entendia, insultando burguês e até jovens contestatários de esquerda (dos cafés) ou pondo a mão marota onde o pudor alheio tho proibia (PACHECO, 2004, p. 33-34). 
Como é verificado no trecho, há o início de uma tomada de consciência por parte do narrador: as badernas provocadas por eles, e pelo amigo em especial, começam a incomodá-lo. O distanciamento causado pela consciência favorece a dialogia entre as personagens, bem como a percepção do outro como "o alheio", logo, a criação de um juízo de valor sobre a conduta do amigo revela-se.

Depois da aceitação da existência do problema, surge a busca pela cura. Apesar de saber que o amigo era "maluco", o narrador não gostaria que ele fosse internado em um dito hospício. Um tempo depois, chegou à conclusão de que não havia mais possibilidade de conviver com o amigo devido à doença do alcoolismo. Neste ponto, o narrador começa a pensar na busca por alternativas para a melhoria da situação de saúde do amigo antes que algo pior lhe acontecesse:

\begin{abstract}
Farto de tantas chatices, resolvi dar-lhe fim de maneira científica. Ouvira falar em curas de desintoxicação e que, no Júlio de Matos, tratavam disso a preceito, por métodos modernos, com os recursos das técnicas mais avançadas. A ideia andou a germinar-me no caso meses e fio e não me animava lá muito: sugeriame, com pavor, um hospício recheado de maluquitos, cuja convivência me afligia, onde se entra para não mais sair (acontecera o mesmo a um tio meu materno no Telhal, que nunca quis conhecer, tinha medo). Receava que, a levalo ali na melhor das intenções e deixá-lo internado, lhe descobrissem maleita hereditária ou adquirida e não o largassem. Que ele era um psicopata, quem o duvidava? Atormentou-me, confesso, esta hesitação até que um dia me resolvi. O nosso homem excedera as marcas. Tinha de ser (PACHECO, 2004, p. 34).
\end{abstract}

Começa, aqui, a explicitação da axiologia impressa à obra, a qual está permeada pela naturalidade com a qual o autor-criador trabalha o tema do alcoolismo. Desta forma, é produzido um efeito de enfrentamento a uma doença que ainda causa a exclusão social de muitas pessoas. A voz constitutiva da obra literária pertence ao autorcriador, que escolhe a axiologia que será trabalhada na narrativa, no caso, o alcoolismo, as suas consequências sociais e a necessidade de cura para esta doença. Toda esta percepção emerge da voz do herói, o qual passa a buscar uma cura "científica" para a doença do amigo, uma vez que as tentativas “caseiras” de recuperação do vício do álcool tinham falhado.

Ao chegarem ao centro de reabilitação, o narrador percebeu que o amigo ficaria em boas mãos, ainda que tenha achado o local "aborrecido": 
O internamento, de momento, era impossível. Não havia vagas, a bicha de borrachões necessitados à nossa frente excedia a lotação. Mas levados fomos à presença da dra. Maria Odília, vi-o de todo perder a timidez e o medo. Também logo percebi que o deixava entregue em boas mãos (PACHECO, 2004, p. 35).

Como não havia vagas, o amigo foi submetido a um tratamento em casa, conforme segue:

O tratamento preceituado, dito ambulatório (em regime de externato), resumia-se afinal a uma picada na veia - não dói nada - e pastilhas tranquilizantes às refeições, que não amargam na boca e é de toda a conveniência engolir com água simples. Mais nada. Lá fora, evitar os tascos e as más companhias aliciantes, vencer as pérfidas tentações, calminha, muita calminha! Ingerir líquidos (sem cheiro de álcool) o mais possível, para lavagem das tripas e mente sã. O meu amigo, que já quase não comia (facto observável nos grandes bebedores), à terceira injecção do cocktail de vitaminas ganhou um apetite dos diabos. Passadas poucas semanas parecia outro (PACHECO, 2004, p. 35, grifos do autor).

No trecho, as vozes se misturam: a voz da médica ao prescrever o tratamento e as vozes do Luiz, narrador, e do seu amigo Luiz. As duas últimas vozes citadas estão explicitadas nos trechos em que há valoração sobre a medicação usada: "não dói nada” e “não amargam a boca”. É nítido que o narrador, na pele do amigo, fez o tratamento para que pudesse saber, com tanta propriedade, os efeitos deste ou daquele remédio. As personagens, aqui, têm os seus contornos colocados em sobreposição: são uma "pessoa só". Ademais, as instruções que se seguem ao receituário, como evitar as "más companhias”, resistir às tentações e ter “calminha, muita calminha!”, também são expressões que evidenciam um bom domínio sobre o tratamento médico realizado, além de trazerem juízos de valor que são consequências da conquista de uma consciência a respeito do alcoolismo. Por fim, o trecho "Passadas poucas semanas parecia outro" denota que houve "de verdade" uma profunda mudança na vida da personagem Luiz. Entretanto, afirmar isso com tanta certeza também é um caminho de indução para a percepção de que há uma sobreposição entre as duas personagens: Luiz, o narrador, é o Luiz, seu amigo.

Já no desfecho da narrativa, a axiologia é completamente revelada ao leitor quando o narrador reflete sobre a situação de exclusão social à qual está sujeita um 
homem alcoólatra. Como foi dito, um dos temas essenciais da obra de Pacheco é discutir e apontar a hipocrisia da sociedade para ela própria por meio da transgressão das regras impostas por esta mesma coletividade. Assim, o narrador conta que, apesar do tratamento, o amigo teve algumas recaídas e voltou a beber:

Não ficava autêntica a história, por incompleta, se lhes ocultasse que teve recaídas. Eis a sua ficha clínica: primeira consulta e princípio da cura de desintoxicação: 13 de agosto de 1969; a 19 de setembro já recuperado. Recaída e novo tratamento a 23 de janeiro de 1970, finalizando em março. Terceira recaída em 14 de maio de 1971: sarado a 2 de junho p.p. (PACHECO, 2004, p. 35)

No exemplo, o narrador dirige-se aos leitores pelo uso do pronome "lhes". Ao conversar diretamente com o leitor em um tom de seriedade ainda não visto no texto, o herói dá um aspecto de verossimilhança à narrativa, singularmente quando lista as datas e a trajetória do amigo entre recuperações e novas voltas ao ambulatório. A austeridade impressa a este parágrafo leva o narrador a expressar a axiologia que foi escolhida para presidir o conto: reflexões a respeito do alcoolismo e da hipocrisia social que permeia a doença, uma vez que a sociedade que incentiva "os copos" é a mesma que condena e exclui o sujeito que se torna viciado em álcool.

O parágrafo que segue traz uma "análise" proposta pelo próprio narrador: a sociedade contribui para o vício? Como é marca recorrente na obra de Pacheco, ele "coloca o dedo na ferida" da sociedade, por um lado, quanto ao abuso do álcool e, por outro, quanto à falta de compreensão das pessoas quanto ao vício: "coisas de bêbado", dizem e riem aqueles que patrocinam a bebedeira no balcão do bar, os mesmos que viram as costas quando o sujeito, já muito embriagado, está precisando de ajuda, caído na sarjeta:

Estas regressões me obrigam a uma pequena análise. Conheço os motivos, todos os antecedentes imediatos e causas longínquas. Assim como há loucos de meio, isto é, a doidice os ataca por um determinado teor de vida, um comportamento rotineiro para o qual não enxergam outra solução que o paraíso artificial que o álcool proporciona, há os doentes da pinga que, mesmo após a cura de desintoxicação, voltam à mesma vida; idênticos problemas os afligem, quer de natureza econômica quer outra e sem coragem ou meio eficaz de os vencer, o escape, a falsa solução ou saída, é ainda e outra vez a bebida. A única de que julgam dispor. Chamemos-lhes então desgraçados e ponhamos a mão na nossa consciência, interroguemo-nos se não contribuímos um tanto para isso - os familiares, os amigos, os companheiros de trabalho. Se as nossas frustrações os 
não atingem também. Mais fácil, mas cruel e criminoso, é troçar dum bêbado do que levantá-lo da valeta e ampará-lo até casa, compreendê-lo e tentar auxiliá-lo. É isto, me parece, uma tarefa colectiva num país onde o alcoolismo atinge taxas elevadas (PACHECO, 2004, p. 35, grifo do autor).

Como é notável, conforme o narrador, a sociedade ignora que o alcoolismo é uma doença e que, por isso, o indivíduo alcoólatra precisa de tratamento médico. Ignora, ainda, as possíveis motivações do sujeito para se entregar ao álcool. E ignora também que, muitas vezes, é a própria marginalidade imposta ao indivíduo pela sociedade que o empurra ao abuso da substância etílica: "sem beber gota de álcool durante meses e que de repente (por um piparote sentimental, um traumatismo inesperado) se lança outra vez na reboleira das cervejas e etc., conforme as sucessivas crises o demonstram, para já uma vantagem lhe assiste" (PACHECO, 2004, p. 36). Assim sendo, a voz do herói se contrapõe à voz da coletividade, conforme a qual o álcool é uma substância de uso recreativo e que, por isso, seu uso é lícito e incentivado. Como acabamento, o narrador afirma que Portugal é um país com altas taxas de alcoolismo e nada é feito pelo poder público.

E, no caso de alcoólatras que conseguiram se afastar do vício e depois voltaram por questões da vida, a voz da moralidade diz que eles já sabem o caminho para a recuperação, uma ida ao centro António Flores, fato este que agrava ainda mais o descuido social para com o alcoolismo:

\footnotetext{
Sabe como parar. No plano inclinado por onde um alcoólico se deixa escorregar à degradação física, mental, social - ele, pelo menos, e quantos o Centro acompanha e acautela por consultas periódicas, tomaram consciência de como travar. A tempo e onde. E com quem. Ali nunca se repelem, sequer os censuram. Quase diria que os aguardam, se após prolongada ausência lhe reaparecem coradinhos na penca, olhos dilatados e raiados ou cútis tostada de figadeira, titubeantes nas pernas e nas falas. Nem devem ignorar - seria estultícia - que o seu passado mórbido e mais as recaídas lhes não deixaram cicatrizes por dentro - nas vísceras, no córtex. Aguentarem-se é pois com eles. Acorrer ao Centro para que os ajudem, deles só depende. A Sociedade... bem, a Sociedade podia e devia intervir. Não por uma inútil, obtusa lei seca - no país das Uvas, imaginese!... que mina para os especuladores, os traficantes - mas por uma reformação geral que excede este depoimento (PACHECO, 2004, p. 36, grifos do autor).
}

Para fechar, o narrador conclui que uma "lei seca" seria um disparate no "país das Uvas”, além de não ser suficiente porque iria incentivar o mercado ilegal de álcool. De 
novo, a voz do herói se coloca contra a voz da coletividade. Em outras palavras, o narrador faz um paralelo entre a facilidade de acesso à substância, uma "droga" legalizada, e a culpabilização do doente no caso de dependência química. Enfim, para ele, o ideal seria informar a população portuguesa sobre o alcoolismo por meio de uma educação preventiva, e não punitiva. Assim sendo, Pacheco, ao criar um novo ser, mesmo que "de papel", coloca-se em dialogia com o autor-criador, o herói e o todo artístico, o que favorece a criação de uma consciência exemplar a respeito de um problema que ele mesmo viveu: o vício em álcool.

\section{Considerações finais}

De acordo com os apontamentos bakhtinianos, o autor de um texto é aquele que se responsabiliza pelo seu ato discursivo. Assim, tratar de "sua" verdade durante um regime ditatorial é, por parte de Pacheco, responsabilizar-se pelo seu dizer, logo, o jogo de máscaras elaborado no conto permite que o autor empírico fale o que tem vontade por meio do seu acobertamento sob os véus de um narrador e de uma personagem, ambas homônimas do autor-pessoa. Obviamente, escolher o mesmo nome para as personagens contribui para a identificação do Luiz Pacheco empírico, o qual, ao mesmo tempo em que se resguarda por detrás de suas criações literárias, busca formas de criticar os dogmas sociais vigentes explicitamente. Daí o jogo autoral.

No conto, nota-se uma preocupação de Pacheco em mostrar que o autor empírico pode assumir uma identidade literária ou não, ao mesmo tempo em que a personagem pode ser ou não um duplo do seu autor empírico. Em outras palavras, não há necessidade de um absoluto aclaramento de tais questões porque são elas, exatamente, que dão maestria à produção literária aqui discutida. Assim, Pacheco busca se afastar da dialética que separa o mundo real do mundo ficcional, o que é um desafio aos limites da concepção corrente de autoria, derivando daí a sua principal marca artística: a sobreposição de "eus", sejam eles empíricos ou "de papel”, no jogo entre a palavra monovocal do autor-pessoa e a palavra bivocal do autor-criador. No contexto criado, a 
máscara autoral permite que Pacheco seja ele e os outros ao mesmo tempo, por isso, ela é libertadora no universo pachequiano.

\section{Referências}

BAKHTIN, M. Problemas da poética de Dostoiévski. Trad. Paulo Bezerra. Rio de Janeiro: Forense Universitária, 1997.

. Estética da criação verbal. 6. ed. Trad. Paulo Bezerra. São Paulo: Martins Fontes, 2011.

CORREIA, N. (Org.). Antologia de poesia portuguesa erótica e satírica. Lisboa: Antígona Frenesi, 2000.

FARACO, C. A. Autor e autoria. In: BRAIT, B. (Org.). Bakhtin: conceitos-chave. 4. ed. São Paulo: Contexto, 2006. p. 37-6o.

GEORGE, J. P. Puta que os pariu! Biografia de Luiz Pacheco. Lisboa: Tinta da China, 2011. MARCHEZAN, R. C. A noção de autor na obra de M. Bakhtin e a partir dela. Bakhtiniana, São Paulo, v. 10, n. 3, p. 186-204, set./dez. 2015. Disponível em: <https://revistas.pucsp.br/index.php/bakhtiniana/article/view/22365>. Acesso em: 10 jun. 2019.

MARTINS, F. (Org.). O espelho libertino. São Paulo: Escrituras, 2007.

NARCISO, S. O caso autoral de Luiz Pacheco: alguns equívocos sobre a interpretação biografista de sua obra. Lisboa: Centro de Literaturas e Culturas Lusófonas e Europeias, 2012.

PACHECO, L. Historieta [1971]. In: GEORGE, J. P. Luiz Pacheco em Massamá ou o retrato do escritor quando alcoólico. Periférica, n. 8, 2004.

TEZZA, C. Sobre O autor e o herói - um roteiro de leitura. In: FARACO, C. A.; TEZZA, C.; CASTRO, G. de. (Orgs.). Diálogos com Bakhtin. 4. ed. Curitiba: Universidade Federal do Paraná, 2007. 
PUGINA, Rosana Letícia

Recebido em 02/02/2020.

Aprovado em 14/05/2020.

Revista Investigações, Recife, v. 33, n. 1, p. 1 - 20, 2020 ISSN Digital 2175-294X 